\title{
THE GROWTH OF MEDICAL TOURISM AND THE IMPACTS ON LOCAL WELLBEING EQUALITY: A CASE OF THAILAND
}

\author{
Ahmad Mujafar SYAH* \\ Naresuan University International College, Department of International Tourism \\ \& Hospitality Management, Phitsanulok, Thailand, e-mail: ahmadmu@nu.ac.th \\ Kamphon DEEMOD \\ Naresuan University International College, Department of International Tourism \\ \& Hospitality Management, Phitsanulok, Thailand, e-mail: kamphond59@nu.ac.th

\section{Liou-Yuan LI} \\ Rajamangala University of Technology, Faculty of Business Administration, Thanyaburi, Thailand, e-mail: liou_y@rmutt.ac.th \\ Arifin ROSMAN \\ Naresuan University International College, Department of International Tourism \\ \& Hospitality Management, Phitsanulok, Thailand, e-mail: arifinro61@nu.ac.th

\begin{abstract}
Citation: Syah, A.M., Deemod, K., Li, L.Y., \& Rosman, A. (2022). THE GROWTH OF MEDICAL TOURISM AND THE IMPACTS ON LOCAL WELLBEING EQUALITY: A CASE OF THAILAND. GeoJournal of Tourism and Geosites, 40(1), 200-209. https://doi.org/10.30892/gtg.40124-820
\end{abstract}

\begin{abstract}
Within the Asia-Pacific region, the growth of medical tourism (MT) in Thailand has been gearing toward a monumental progress. Consequentially, the various research of its policy, strategy and service management have been explored and furthered. Contradictory, the study of local wellbeing equality over the MT has, unfortunately, been in hiatus. The objective of the study is to further the current premise of the literature, test, and prove; arguing that from Thai society's perspectives, the promising MT growth in the kingdom does not necessarily mean an equal establishment of the community's wellbeing. A quantitative methodology employed and linear regression by SPSS run. Of 600 online and paper questionnaires distributed to Thai's medical doctors, resident doctors, medical students (senior year), and tourism scholars, 528 responses were attained. All four tested hypotheses on the perceived growth of Thailand's MT toward local community's unequal economic, social, healthcare, and environmental aspects, approved. That interprets the issue of policy isolation between MT's investment versus community's benefits.
\end{abstract}

Key words: Thailand's Medical Tourism, Medical Tourism Growth, Impact Assessment, Local Wellbeing, Equality

\section{INTRODUCTION}

\section{A Brief History of Medical Tourism in Thailand}

Post the 70s, the rise of the medical tourism (MT) trend in Thailand had been exponential - thanks to a fit of emerging interests in Western countries regarding the travel access-friendly, reasonable rates of cosmetics, wellness treatment, facial rejuvenation, and other elective healing techniques which were not covered by healthcare coverage plans (Almeida García et al., 2015; Cohen et al., 1972; Connell, 2006b; Raggio et al., 2020). At the same time, the treatment availability of rhytidoplasty was at that time, of the mainstream's Thailand's MT's pull factors (Cohen et al., 1972), then, it extended to dental work and more extensive scope of medical treatments. Two vital sources of MT demand are: (1) a couple of developed countries wherein the great quality of medical services are restrictively costly or not promptly available like in down under country Australia, to Japan, United States until the United Kingdom; (2) on the other hand, the access was still fairly limited in the developing countries of Southeast Asia as well as the Middle East like Saudi Arabia, the United Arab Emirates, Cambodia, Myanmar, or Bangladesh (Cohen, 2007). Furthermore, the vast numbers of demand were supported by some political enhancements at that point in time, and by two catastrophic occasions: The 9/11 terrorist tragedy, and Tsunami 2004 (Cohen, 2007). The 9/11 issues had made many Middle Easterners seek medical treatment in Thailand rather than the United States due to travel restrictions (Cohen, 2007; Connell, 2010). Meanwhile, the catastrophic Tsunami in 2004 had unexpectedly built the competitive edge of Thailand's MT. Since other developing countries' hospitals impacted by Tsunami endeavored to adapt to the high number of fatalities, Thailand acquired worldwide exposure for its medical agility, and unexpectedly receiving a surprising reputation outside the country which captivated outsiders to consider Thailand as a prominent destination for international healthcare hub (Cohen, 2007; Connell, 2010). Growing steady with promising healthcare treatments and services reputation, Cohen (2007) recalled the data; of 30\% of the aggregate growth within the 2000s, with the record of the tourists visiting Thailand with an exclusive purpose of MT. This rate would have been logical as the medical treatment of Thailand's medical technology has constantly developed; with more medical centers

\footnotetext{
* Corresponding author
} 
providing bundling packages of medical treatment and leisure; extensive medical technology invested, as well as great support of Thailand's government under the campaign of" wellbeing hub" were all enacted within Thailand's government sound management (Cohen, 2008). The medical service's reputation in Thailand has sequentially been supported by different government-sponsored promotional campaigns; the most distinguished among them is the "Amazing Thailand" campaigns featuring "the attractions of spas, herbal products as well as hospitals" (Alberti et al., 2014; TAT, 2020; KPMG, 2018).

\section{Current Standing and Growth of Medical Tourism in Thailand (2018 - 2020)}

KPMG (2018) released Thailand's MT sector report on an initiative of global "Medical Hub" policy in the Kingdom. This initiative is being represented as the country's new engine of growth gearing both national healthcare development and its offers to all the world's patients. Additionally, "Medical Hub" is a regional catalyst targeting society development. The influence of Thailand's medical industry agility in formulating the pharmaceutical logistics and supply chain, the healthcare industry, and biotechnology to exercise the resilience of national economics and its competitiveness for the longterm plan, has been continuously praised (KPMG, 2018). As reported in the white paper of TIR (2020) and socialized by TAT (2020), the initiative gauged the plan of the Ministry of Public Health (MPH) 2016-2025 over Thailand's transformation into the first in the market to offer MT's attractiveness within four key five imperative points in support to MT in the kingdom: wellbeing, excellent healthcare support, advance-research-based medical treatments, as well as medical products. Thailand's MT is committed to offering a competitive edge, international standard of medical service, personalized services of medical staff, and a unique bundle of packages of medical and leisure services (Dang et al., 2020; TIR, 2020). MT demand outlooks, despite the unprecedented pandemic of COVID-19, have moved Thailand's government forward to concentrate investment outlooks in medical and wellness infrastructures. Meanwhile, the endeavor of Thailand's medical tourism promotion as a worldwide medical and wellness destination is fully administered by the Tourism Authority of Thailand in integration of Thailand's travel and tourism systems (TIR, 2020).

The fast-paced and attractive climate of investment in Thailand's international medical services are geared by Thailand's growth consistency in the holistic market share of the travel and tourism sector - not only within ASEAN regions but also globally. Thailand represents true hospitality services over world-class destination management support. The World Bank positions Thailand in the $21^{\text {st }}$ rank among 190 nations under the category index of "Ease of Doing Business in 2020" - mirroring the country's favorable administrative environment for initiating local organizations (KPMG, 2018). Additionally, out of 160 countries, Thailand stands strong as the $32^{\text {nd }}$ nation to perform outstanding "Logistic Performance Index" under the World Bank Criteria, leading almost head to head with Singapore in the ASEAN region (KPMG, 2018). With 370 non-public hospitals, up to 50 are certified by the Joint Commission International (JCI) a global standard, all of them are contemporarily upheld by Thailand's huge medical care industry, while there were additionally 18 JCI-licensed medical centers as of September 2019 (TIR, 2020) . This number is more prominent than some other ASEAN members and fourth-most elevated around the globe (KPMG, 2018). In addition, Thailand's overall medical services network comprises up to 25,000 health facilities, 1,000 public hospitals, 50,000 physicians, and over 10,000 clinics (TIR, 2020)

Table 1. Major Hospital Groups of Thailand's Medical Tourism Industry 2017 (Source: Bangkok Chain Hospital (2017), Bangkok Dusit Medical (2017), Udomvej (2018) - modified from Kaewkamol \& Lim (2021))

\begin{tabular}{|l|l|c|c|}
\hline $\begin{array}{c}\text { Hospital or } \\
\text { Group Name }\end{array}$ & \multicolumn{1}{|c|}{ Ownership Structure } & $\begin{array}{c}\text { Capacity } \\
\text { (beds) }\end{array}$ & $\begin{array}{c}\text { Market Capitalization } \\
\text { (in US\$) }\end{array}$ \\
\hline Bangkok Chain & Harnphanich Family (Thailand, 50\%); Free Float (38\%); Others (12\%) & 2,178 & 1,211 \\
\hline Bangkok Dusit Medical & Prasarttong-Osoth Family (Thailand, 22\%); Free Float (47\%); Others (31\%) & 8,015 & 10,096 \\
\hline Bumrungrad & $\begin{array}{l}\text { Bangkok Bank Public Company Limited (Thailand, 32\%); Free Float } \\
\text { (40\%); Others (28\%) }\end{array}$ & 580 & 4,452 \\
\hline Chularat & Plussind Family (Thailand, 26\%); Free Float (38\%); Others (36\%) & 830 & 696 \\
\hline Siriraj Piyamaharajkarun & State-Owned (Thailand, 100\% & 344 & N/A \\
\hline
\end{tabular}

Regarding the growth of MT, the International Healthcare Research Center (IHRC) reported by KPMG (2018) and TIR (2020) shows that it is anticipated to grow 14\% annually, with $12 \%$ inbound tourists. From an economic development standpoint, the rising wage is potentially leading to a more middle-class economy and affecting their domestic spending especially on a health and cosmetic basis due to the hard pressure of day-to-day work and stress level. As KPMG (2018) added, the Medical Tourism Index (MTI) led by the IHRC, Thailand was ranked 18th to be the most predominant medical tourism destination in 2016, whose industry dominates the top 6 of Thailand' service growth. Thailand is enjoying the reputation to be the number $13^{\text {th }}$ of international-standard facilities and services, along with destination attractiveness index that falls under $27^{\text {th }}$ rank worldwide, and with steady tourist arrival of 25 million for medical and wellness tourism alone as of 2016 (TIR, 2020).

\section{Statement of Problem}

Despite prominent global recognition and promising growth, the discourse of Thailand's MT over local community wellbeing and its imperative on socio-economic and political equality have been lingering for over a decade without any further studies. Whilst, the most current one from Kaewkamol and Lim (2021) distinctively explored the MT shareholders and policy makers perspectives instead. The post study of (Cohen, 2008; Connell, 2010; Noree et al., 2016; Pocock and Phua, 2011), marked a generic, rather embedded thesis over inequality on Thailand's MT ecosystem (e.g. doctor migration problem, domination of private hospitals, the growth of inequity in the urban-rural divine the gap in healthcare cost). 
Whilst, other most current literature are mainly offering frameworks on MT's desired attributed for healthcare services (Wongkit and McKercher, 2016) determinants and influencing factors of MT destination (Zarei et al., 2018), theoretical model of travel motivation, perceived risks and mobility barriers over MT destination image (Khan et al., 2017) and medical marketing in Asia (Zarei and Maleki, 2019). Hence, due to previous studies that are rather specific and over a concerning literature span interval, this study would endeavor to propose a literature novelty over the status quo of Thailand's MT growth over community inequality - and would particularly assess economic, social, healthcare, and environmental factors.

\section{LITERATURE REVIEW}

\section{Theory of Medical Tourism}

MT is said to have been exposed recently, also known to be a late $20^{\text {th }}$ century phenomenon. However, the numerical data found on MT is unreliable and not sufficient to utilize since they depend on industry optimism and boosterism instead of the rigorous study (Hopkins et al., 2010; Johnston et al., 2010). With regards to medical care, traveling has been long existed and destination such as Harley Street, London has been known as a famous international center of medical care until the impact of "reverse globalization" took place just two decades ago which brought about developed countries' patients making their ways to developing countries for medical care because of homeland's high cost for treatment, accessibility, service, and also quality issues (Connell, 2013). People do tend to perceive MT as a means of traveling overseas - getting medical check-ups as well as having a chance to fulfil one's physical and mental needs and wants (Connell, 2013). From a niche industry-wise, MT took place when patients travel overseas to receive medical, dental, and surgical treatment, while also spending time on their holiday at their respective destinations - hence, it is categorized as travel and tourism activity (Connell, 2006a). Some scholars suggest the main goal of going on MT, as it has in a constant search to separate "medical tourism" from "health tourism" is focusing toward "the performance, low-key, therapeutic, as well as non-invasive method" (Connell, 2010, 2013). It is a traveling process that might bring about medical acts such as allowing dental activities and check-ups (Connell, 2013). Whereas Johnston et al. (2010) indicate the MT where patients traveling to another country beyond the authorized jurisdiction, with treatment is intended toward medical support and care, particularly aimed for the surgeries.

Thompson $(2008,2011)$ differentiates medical tourists as "qualified biosocial citizens" opposed to "medical migrants", whose names are rightly regulated through institutions on behalf of making personal decisions. Although the word "migrant" can be argued to be logical as (Glinos et al., 2010) emphasize that MT is the act of patients who seek healthcare abroad due to the limited quality of their own national healthcare system. Thus, in a more medical term, medical tourists may be considered as patient consumers - where it is deemed as an economic activity between two sectors in a service term. e.g. medical tourism $=$ medicine + tourism (Bookman and Bookman, 2007; Connell, 2013). The Europe's case study explained the finding on the pull factor of patients' motivation towards outside borders medical treatment that are based by "availability, affordability, familiarity, and perceived quality" of MT's destinations (Connell, 2013: 2). Simply put, it is surprisingly unusual to point out that other than in nomenclature, tourism has not been formally discussed of international medical travel" (Connell, 2010, 2011; Laugesen and Vargas-Bustamante, 2010). Another claim, a vacation with traveling abroad to obtain medical services, should include relaxation activities (Connell, 2006b; Heung et al., 2010). Most recently, Cham et al. (2020), Raggio et al. (2020) and Zarei et al. (2018) mentioned the potential pull factors of MT as an emergent niche industry, from several different analysis such as better service quality, various leisure offers and budlings, value of money, and medical legal systems. While Cham et al. (2020) explored the generic premise of MT as an overarching offer of healthcare capped with tourism services like beach visit, wellness experience, and/or religious retreat, Zarei et al. (2018) touched the core attarctive factor of MT as an avenue for an individuals to seek legal procedure of physical sexual indentity changes whereby the home country's laws may hinder. Closely related to Zarei's study, the MT's emphasis of Raggio et al. (2020) is no longer the idea of foreign traveller seeking medical treatment in the MT's providing countries. Rather, enabling discussion on how possible legal dispute on medical treatement of facila rejuvenation (cosmetic surgery) understood.

\section{The Manifestation of the Competitive Advantage Framework on Medical Tourism Growth Analysis}

Izadi et al. (2012) reflect on the competitive advantage framework in defining the competitive edge indicators for MTgrowth's policy analysis in Iranian business landscape. They mapped generic MT's competitive advantage and its relationship based on two distinctive mutual sequencing: (1) factors causing competitive advantage that include function excellence, quality excellence, customer response excellence and innovation; (2) relationship between factors causing competitive advantage that highlights critical factors of unique resources and capabilities under distinct competence criteria such as affordability, excellent service performance, accredited quality, and responsiveness to tourists (Izadi et al., 2012).

As Izadi et al., (2012) extend their framework, they came up with five competitive underpinning for MT growth basing value resources (e.g. MT physical, research, medical specialty supports), capabilities (e.g. advanced services in various surgeries), distinct competencies (e.g. specific pull factors of MT in Iran such as affordability, travel attraction, and culture), particular advantages (e.g. geographical location) and drawbacks (barriers of MT growth in Iran). Consequently, this published competitive advantage framework proposed by Izadi et al. (2012) is complicated, reconceptualized, and adjusted to accommodate the narrative framing of perceived growth of MT in Thailand context (independent variables).

\section{The Impacts of Medical Tourism on Local Communities}

Throughout the whole published research papers regarding all types of tourism, MT is still over the discourse in terms of its impacts towards the quality of life of the local community (Kim et al., 2015). It can be said quality of life is a complicated concept, consisting of multidimensional, environmental and inter-active domains that cover the aspect of lives 
and the environment in certain ways (Sirgy et al., 2000). Thus, when the local people and their social, economic, and environmental aspects change, their perceptions of the community would also change. Previous researches have shown that tourism brings about benefits and costs towards a community, and it has both positively and negatively influenced a community's quality of life (Almeida García et al., 2015; Bramwell and Lane, 1993; Haywood, 1988; Johnson et al., 1994; Lawrence et al., 1988; Liu et al., 1987; Liu and Var, 1986; Mccool and Martin, 1994; Pearce, 2009; Perdue et al., 1990; Sharpley, 2000; Suess et al., 2018; Kaewkamol and Lim, 2021). Some studies have investigated community well-being regarding the local community's assessment on the impacts of tourism (McCabe and Johnson, 2013). Weaver and Lawton (2001) explain that the states of wellbeing within the community involve living experiences and living satisfaction in a community. Whist, Hansruedi (1994) urges to address the subjective wellbeing of local residents. Correspondingly, Uysal et al. (2016) points out that local community subjective wellbeing is a significant aspect of both emotional and physiological experiences which the local or national tourism planner should take into account within their implementation agenda. Thus, the subjective wellbeing of local residents should be priorities for the community's quality of life and partnering with living experiences and community satisfaction by practicing tourism towards the community (Uysal et al., 2016). Holistically within general tourism's impact studies toward the quality of life of a local community, the approved measurement indicators of impacts range from (1) economic and healthcare impacts such as the quality of local community infrastructure for healthcare facilities and standard of living; (2) social development measurement over the equal provision of public service supports as well as a social network establishment; (3) environmental aspects range from the conserved natural resources over the growth of mainstream tourism, and control of country/regional's pollutions due to tourism; (4) healthy culture and political impacts can be measured by the landscape quality of local community area, preservation of local culture, cultural confidence, physical amenities, as well as local community protection from foreign cultural impacts; (5) specific local community wellbeing ranges from high-standard of good living experience over tourism growth as well as local community satisfaction toward the government (Andereck and Nyaupane, 2011; Chuck et al., 1985; Clare and Var, 2002; Filkins et al., 2000; Goudy, 1990; Grzeskowiak et al., 2003; Hansruedi, 1994; Kasarda and Janowitz, 1974; McGehee and Andereck, 2004; Nunkoo and Ramkissoon, 2012; Sirgy et al., 2000; Sirgy and Cornwell, 2001; Suess et al., 2018; Weaver, 2005). Even though Kuvan and Akan (2005) noted that local communities who are economically breathing from the tourism growth perceived merely positive impacts, the studies of negative impacts from tourism development, especially medical tourism, could not emphasize more concerns and further discourses (Connell, 2013; Suess et al., 2018). From the literature reviews, the authors found out the novelty in the study of Thailand's niche MT industry growth toward the assessment of equality on local community's wellbeing - which in the Thailand context, has not yet been systematically examined by the scholarly research. Notably, the study rigorously explores and seeks out the unresolved facts of the true medical tourism's impacts being testified by hands on of Thai' medical doctors, resident doctors, medical students (senior year), and tourism scholars within the Kingdom.

\section{RESEARCH METHODOLOGY}

\section{Hypothesis}

Based on the robust underpinnings from the literature reviews on MT competitiveness and growth factors, as well as the aspects of local community's impacts over MT sector, the research constructs the hypotheses where independent variables are the perceived growth of medical tourism in Thailand, and dependent variables are inequalities on economic, social, healthcare, and environment (illustrated in Table 1). Nonetheless to say, within the dependent variables, the political impact as resonated by Suess et al. (2018) is not exercised in respective manner as the political support ideas to the local community have been embedded comprehensively in the economic, social, and environmental concern areas.

H1: The perceived growth of medical tourism in Thailand has not been fully contributing to the healthcare equality of the Thai local community

H2: The perceived growth of medical tourism in Thailand has not been fully contributing to the economic equality of the Thai local community

H3: The perceived growth of medical tourism in Thailand has not been fully contributing to the social equality of the Thai local community

H4: The perceived growth of medical tourism in Thailand has not been fully contributing to the environmental equality in the Thai local community

\section{Sampling and Data Collection}

This research employed quantitative methodology where primary data gathered from the respondents by questionnaire. From October 2020 until April 2021, of 600 online and paper questionnaires distributed and 528 responses were successfully returned, making it $88 \%$ of the response rate. The primary data is gathered from first-hand sources of Thai's medical doctors, resident doctors, medical students (senior year), and tourism scholars, in order to fully reflect the accuracy of the issue and maximize the quality of the responses (Aldiabat and Navenec, 2018). Non-probability sampling technique (purposive sampling) is employed to reach the targeted respondents effectively. The questionnaires are divided into 3 different sections: (1) Demographic profile; (2) Perceived Growth of Medical Tourism in Thailand (3) Impact assessments of Thailand's medical tourism toward local wellbeing equality focusing on economic, social, healthcare, and environmental impacts. Of questionnaires 2 and 3, 5-point Likert scale (1 "strongly disagree" and 5 "strongly agree") employed.

\section{Data Analysis}

The data were processed by SPSS software where descriptive statistics of demographic profile, exploratory factor 
analysis of questionnaire variables, and linear regression analysis of the hypothesis were tested. The Cronbach's $\alpha$ was also run. According to Zikmund et al. (2010), the Alpha 0.7 works as an accurate guide (rule of thumb) to indicate internal reliability's acceptable level. The reliability test was run to examine if the data and the construct are reliable. The table shows that Cronbach's $\alpha$ is higher than 0.6 for all variables. The alpha 0.6 is considered as fair reliability, and the higher alpha is considered better reliability. To ensure the holistic frameworks' reliability, Cronbach's $\alpha$ was run both for questionnaire items of independent and dependent variables.

\section{Research Framework}

Self-developed questionnaire was developed and was subjected to back-to-back reviews of ten assigned experts to validate accurate indicators of MT's growth factors, and to avoid ambiguity in wordings. Four of the experts are Thai's medical doctors, three tourism policy professors in Thailand, and three tourism management professors from the United States. Upon completion of the first round of survey validations, fifty questionnaires were distributed for pilot study in September 2020. Minor feedback from respondents were attained and final expert evaluations undertaken.

Table 2. Framework and Cronbach's Alpha (Reliability) (Source: Authors)

\begin{tabular}{|c|c|c|}
\hline $\begin{array}{l}\text { Independent } \\
\text { Variables }\end{array}$ & Questionnaire items & $\begin{array}{c}\text { Cronbach's } \\
\alpha\end{array}$ \\
\hline \multirow{5}{*}{$\begin{array}{l}\text { Perceived } \\
\text { Growth of } \\
\text { Medical } \\
\text { Tourism }\end{array}$} & $\begin{array}{l}\text { Thailand has valuable resources for MT (e.g. international-standard laboratory; specialist in dentistry, cardiology, and } \\
\text { cosmetics treatment; various sub-specialist of medical faculty and research centers; and integrated leisure supports) }\end{array}$ & .733 \\
\hline & $\begin{array}{l}\text { Thailand has great capabilities for MT (e.g. continuous global recognition and accreditation in most } \\
\text { advanced surgeries with committed policy of anti-medical malpractice) }\end{array}$ & .735 \\
\hline & $\begin{array}{l}\text { Thailand has distinct competencies for MT (e.g. low-cost medical fee recognition with qualified doctors; English } \\
\text { proficiency; welcoming Asian culture; beautiful tourist destinations; and excellent hospitality services and bundles) }\end{array}$ & .748 \\
\hline & $\begin{array}{l}\text { Thailand has particular advantages for MT (e.g. strategic geographical advantages; leading global tourism } \\
\text { hub; high demand of MT from neighboring countries; high number of expatriates) }\end{array}$ & .621 \\
\hline & $\begin{array}{l}\text { Thailand government support on MT is exceptional (e.g. exceptional national budget for healthcare sector; } \\
\text { great incentive policy for MT; investments on innovation, advanced medical technology, hospital facilities, } \\
\text { accommodation and destination facilities, logistics infrastructure, and R\&D; exceptional budget for } \\
\text { international MT promotion and marketing; VISA and tourist safety) }\end{array}$ & .731 \\
\hline $\begin{array}{l}\text { Dependent } \\
\text { Variables }\end{array}$ & Questionnaire items & $\begin{array}{c}\text { Cronbach's } \\
\boldsymbol{\alpha}\end{array}$ \\
\hline \multirow{5}{*}{$\begin{array}{l}\text { Economic } \\
\text { Inequality }\end{array}$} & Lack of equal establishment of community infrastructures & .639 \\
\hline & Not better off standard of living & .657 \\
\hline & Not better off employment opportunity & .846 \\
\hline & More monopoly of private hospital over public hospital & .732 \\
\hline & More income disparity between private medical worker and public medical worker & .733 \\
\hline \multirow{4}{*}{$\begin{array}{l}\text { Social } \\
\text { Inequality }\end{array}$} & Lack of equal healthcare's service provider provision between medical tourism providing cities and community areas & .775 \\
\hline & $\begin{array}{l}\text { Lack of equal community's social service support provision (e.g. mental support, depression, physical } \\
\text { illness, smoking \& alcohol abuse) }\end{array}$ & .780 \\
\hline & Lack of social inclusion in affordable/subsidized medical education access to all citizens & .621 \\
\hline & Lack of social participation in the medical tourism investment decision making & .831 \\
\hline \multirow{4}{*}{$\begin{array}{l}\text { Healthcare } \\
\text { Inequality }\end{array}$} & Lack of equal provision on more advanced, speedier, and affordable healthcare treatment for the community & .733 \\
\hline & Lack of equal provision on skilled doctor both in the medical tourism providing cities and community areas & .855 \\
\hline & $\begin{array}{l}\text { Lack of good control of the significant risk of bacterial travel and communicable disease from medical } \\
\text { tourist to the community }\end{array}$ & .758 \\
\hline & Mortality rates in underdeveloped community towns are still overwhelming & .633 \\
\hline \multirow{5}{*}{$\begin{array}{l}\text { Environment } \\
\text { al } \\
\text { Inequality }\end{array}$} & Insufficient availability of community's landscapes and green spaces including public parks and safety pedestrian & .862 \\
\hline & Lack of good control of significant air pollution due to congestion of medical tourism transports & .734 \\
\hline & Lack of good control of significant noise pollution due to congestion of medical tourism transports & .634 \\
\hline & Lack of good control of the significant impact of medical's solid-toxic waste & .739 \\
\hline & $\begin{array}{l}\text { Lack of good control of the significant impact of the community's water supply due to the growth of } \\
\text { wellness facilities such as hotels, spas, swimming pools }\end{array}$ & .740 \\
\hline
\end{tabular}

\section{RESULT}

The demographic data on gender comprises $36 \%$ male and $64 \%$ female. The age group of the respondents from $20-$ 25 years old accounted for $34 \%, 26-30$ years old at $3 \%$, and the $>30$-year at $62 \%$. The majority of the respondents are medical doctors at $54 \%$, followed by medical students (senior year) at $19 \%$, resident doctors at $17 \%$, and tourism scholars at $10 \%$. Whilst, $38 \%$ of the respondent population coming from North of Thailand, South of Thailand accounted for $7 \%$ followed by $5 \%, 8 \%, 8 \%$, and $34 \%$ for East, West, Northeast, and Central of Thailand respectively. Over $95 \%$ confidence level, the linear regression results show statistical significance of respective dependent variables (economic inequality, social inequality, healthcare inequality \& environmental inequality) at .000. that interpret
Table 3. Demographic Profile

\begin{tabular}{|l|c|c|l|c|c|}
\hline Gender & $\mathbf{N}$ & $\mathbf{\%}$ & Respondent Group & $\mathbf{N}$ & $\mathbf{\%}$ \\
\hline Male & 190 & 36 & Medical Doctor & 287 & 54 \\
\hline Female & 338 & 64 & Resident Doctor & 92 & 17 \\
\hline Other & 0 & 0 & Medical Student (Senior-Year) & 98 & 19 \\
\hline Total & $\mathbf{5 2 8}$ & $\mathbf{1 0 0}$ & Tourism Scholar & 51 & 10 \\
\hline Age & $\mathbf{N}$ & $\mathbf{\%}$ & Total & $\mathbf{5 2 8}$ & $\mathbf{1 0 0}$ \\
\hline $20-25$ & 182 & 34.5 & Respondent Origin & $\mathbf{N}$ & $\mathbf{\%}$ \\
\hline $26-30$ & 18 & 3.4 & North of Thailand & 201 & 38 \\
\hline$>30$ & 328 & 62.1 & South of Thailand & 38 & 7 \\
\hline Total & $\mathbf{5 2 8}$ & $\mathbf{1 0 0}$ & East of Thailand & 28 & 5 \\
\hline & & & West of Thailand & 40 & 8 \\
\hline & & Northeast of Thailand & 41 & 8 \\
\cline { 3 - 6 } & & Central of Thailand & 180 & 34 \\
\cline { 3 - 6 } & & Total & $\mathbf{5 2 8}$ & $\mathbf{1 0 0}$ \\
\cline { 3 - 6 } & & & & \\
& & & & & \\
\end{tabular}


the approval of all constructed hypotheses (illustrated in Table 3, 5, 7 and 9). Whilst, the results of adjusted R-squared of .866 (or $87 \%$ ), .864 (or 86\%), .809 (or 81\%), and .890 (or 89\%) indicate a strong value of predictor variables toward dependent variables on respective economic, social, healthcare, and environmental inequality testing.

Table 4. Hypothetical Testing Result 1 (Source: Authors)

\begin{tabular}{|c|c|c|c|c|c|c|c|c|c|c|c|}
\hline \multicolumn{9}{|c|}{ Coefficients } & \multicolumn{3}{|c|}{ Model Summary } \\
\hline & \multirow[t]{2}{*}{ Model } & \multicolumn{2}{|c|}{$\begin{array}{l}\text { Unstandardized } \\
\text { Coefficients }\end{array}$} & \multirow{2}{*}{$\begin{array}{c}\begin{array}{c}\text { Standardized } \\
\text { Coefficients }\end{array} \\
\text { Beta } \\
\end{array}$} & \multirow[t]{2}{*}{$\mathrm{t}$} & \multirow{2}{*}{ Sig. } & \multicolumn{2}{|c|}{$\begin{array}{l}95.0 \% \text { Confidence } \\
\text { Interval for B }\end{array}$} & \multirow[t]{2}{*}{ R-Square } & \multirow{2}{*}{$\begin{array}{l}\text { Adjusted R- } \\
\text { Square }\end{array}$} & \multirow{2}{*}{$\begin{array}{l}\text { Std. Error of } \\
\text { the Estimate }\end{array}$} \\
\hline & & B & Std. Error & & & & Lower Bound & Upper Bound & & & \\
\hline \multirow[b]{2}{*}{1} & (Constant) & -.160 & .356 & & -.449 & .653 & -.859 & .539 & \multirow[b]{2}{*}{.866} & \multirow[b]{2}{*}{.866} & \multirow[b]{2}{*}{.686} \\
\hline & $\begin{array}{l}\text { Perceived Medical } \\
\text { Tourism Growth }\end{array}$ & .932 & .016 & .931 & 58.279 & .000 & .901 & .964 & & & \\
\hline
\end{tabular}

Table 5. Hypothetical Testing Result 2 (Source: Authors)

\begin{tabular}{|c|c|c|c|c|c|c|c|c|c|c|c|}
\hline \multicolumn{9}{|c|}{ Coefficients } & \multicolumn{3}{|c|}{ Model Summary } \\
\hline & \multirow{2}{*}{ Model } & \multicolumn{2}{|c|}{$\begin{array}{l}\text { Unstandardized } \\
\text { Coefficients }\end{array}$} & \multirow{2}{*}{$\begin{array}{c}\begin{array}{c}\text { Standardized } \\
\text { Coefficients }\end{array} \\
\text { Beta }\end{array}$} & \multirow[t]{2}{*}{$\mathrm{t}$} & \multirow{2}{*}{ Sig. } & \multicolumn{2}{|c|}{$\begin{array}{l}95.0 \% \text { Confidence } \\
\text { Interval for B }\end{array}$} & \multirow{2}{*}{ R-Square } & \multirow{2}{*}{$\begin{array}{l}\text { Adjusted R- } \\
\text { Square }\end{array}$} & \multirow{2}{*}{$\begin{array}{l}\text { Std. Error of } \\
\text { the Estimate }\end{array}$} \\
\hline & & $\mathrm{B}$ & Std. Error & & & & Lower Bound & Upper Bound & & & \\
\hline \multirow[b]{2}{*}{1} & (Constant) & -1.412 & .328 & & -4.305 & .000 & -2.056 & -.768 & \multirow[b]{2}{*}{.864} & \multirow[b]{2}{*}{.864} & \multirow[b]{2}{*}{.632} \\
\hline & $\begin{array}{c}\text { Perceived Medical } \\
\text { Tourism Growth }\end{array}$ & .853 & .015 & .930 & 57.868 & .000 & .824 & .882 & & & \\
\hline & & & & $\begin{array}{l}\text { Predictors: } \\
\text { b. I }\end{array}$ & $\begin{array}{l}\text { onstant) } \\
\text { endent }\end{array}$ & Perce & $\begin{array}{l}\text { ived Medical Tc } \\
\text { le: Social Inequ }\end{array}$ & $\begin{array}{l}\text { ism Growth } \\
\text { ty }\end{array}$ & & & \\
\hline
\end{tabular}

Table 6. Hypothetical Testing Result 3 (Source: Authors)

\begin{tabular}{|c|c|c|c|c|c|c|c|c|c|c|c|}
\hline \multicolumn{9}{|c|}{ Coefficients } & \multicolumn{3}{|c|}{ Model Summary } \\
\hline & \multirow[t]{2}{*}{ Model } & \multicolumn{2}{|c|}{$\begin{array}{l}\text { Unstandardized } \\
\text { Coefficients }\end{array}$} & \multirow{2}{*}{$\begin{array}{c}\begin{array}{c}\text { Standardized } \\
\text { Coefficients }\end{array} \\
\text { Beta }\end{array}$} & \multirow[t]{2}{*}{$\mathrm{t}$} & \multirow[t]{2}{*}{ Sig. } & \multicolumn{2}{|c|}{$\begin{array}{l}95.0 \% \text { Confidence } \\
\text { Interval for B }\end{array}$} & \multirow[t]{2}{*}{ R-Square } & \multirow{2}{*}{$\begin{array}{l}\text { Adjusted R- } \\
\text { Square }\end{array}$} & \multirow{2}{*}{$\begin{array}{l}\text { Std. Error of } \\
\text { the Estimate }\end{array}$} \\
\hline & & $\mathrm{B}$ & Std. Error & & & & Lower Bound & Upper Bound & & & \\
\hline \multirow[b]{2}{*}{1} & (Constant) & -.459 & .371 & & -1.238 & .216 & -1.189 & .270 & \multirow[b]{2}{*}{.809} & \multirow[b]{2}{*}{.809} & \multirow[b]{2}{*}{.715} \\
\hline & $\begin{array}{l}\text { Perceived Medical } \\
\text { Tourism Growth }\end{array}$ & .788 & .017 & .900 & 47.230 & .000 & .755 & .821 & & & \\
\hline
\end{tabular}

Table 7. Hypothetical Testing Result 4 (Source: Authors)

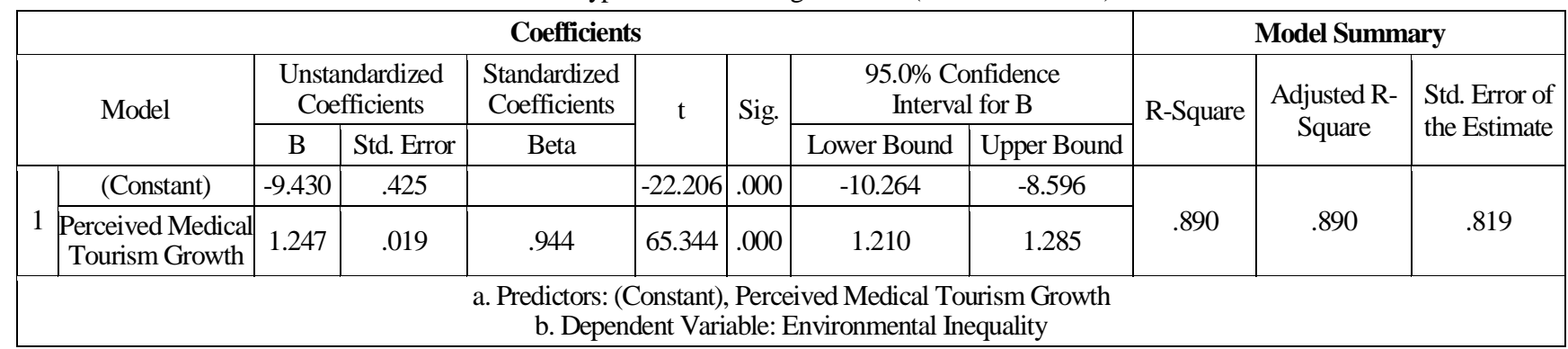

\section{DISCUSSION}

The result of the study, notably within the inequality measurement criteria of healthcare policy for local people, explains that the absence of Thai's local wellbeing equality is believed to be associated with previous MT's statement of the problem in Thailand from Almeida García et al. (2015); Chongsuvivatwong et al. (2011); Cohen (2008); Connell (2006a, 2011). They argued that despite the specific impacted indicators were not identified in the research, it was proven that in general concern, the extensive investment in the private medical centers towards foreign customers, as well as upgrading the medical care facilities that come with more expensive medical fees, have been impacting a specific group of Thai's local patients. As Almeida García et al. (2015); Chongsuvivatwong et al. (2011); Cohen (2008); Connell (2011); Lauridsen (2009) added, middle-class Thais, who would prefer not to depend on the 30-Baht scheme (the affordable medical support program from the Thailand government) as they perceive it to be less appreciated in terms of medical service treatment, found private hospitals to be extremely expensive - so there a huge buying power gap hinders. The issue has validated the real phenomenon of healthcare inequality where equal provision on more advanced, speedier, and affordable health support is still far from being balanced. 
Furthermore, a closely related problem that resonates the finding in the healthcare altogether with economic equality issues is that; there is a term "brain drain" that has been attracted more excelled health professionals as well as medical staff from public hospitals to the private ones - as private hospitals would offer them higher incomes and better working conditions (Cohen, 2008; Connell, 2011; Suess et al., 2018). The phenomenon of migrating doctors and professional healthcare is escalating due to the competing interests of the Thaksin government's health policy. One among the vital outcomes of the 30-Baht scheme has been the growing demand for governmental hospital services as local people are keen to utilize the healthcare benefits (Cohen, 2007; Cohen et al., 1972). To put the issue into the Thai's local economic inequality perspective, the current provision and service quality gap between private and public hospitals in Thailand has been mostly geared by the state's endeavors in order to advance Thailand's MT as a "wellbeing hub," and energize the development of international medical treatment destinations. The effort has successfully opened up economic opportunities for doctors and other medical staff. However, the consequences are unbearable. A significant number of the local doctors and medical professionals leave in pursuit of "better compensation and working conditions in private hospitals" - leaving skilled doctors outside of MT's destinations unequal; let alone the income disparity issues (Cohen, 2008; Connell, 2010). In contrast, public hospitals are under-financed for more advanced technologies while being understaffed at the same time. This condition has made the public hospitals inadequately set up to manage the services toward the constant medical demands (Cohen, 2008). Hence, as the study looks back to the hypothesis on healthcare and economic impacts, it is without surprise, that the finding indicated strong agreements and proved the thesis. Within a local' social sphere, aggravating at the same time, the current inequality in the medical business sphere among suburb and metropolitan regions, and versus the services offered to the wealthy and the less fortunate layers of Thai society has led to the never-ending vicious cycle of social inequality (Chongsuvivatwong et al., 2011; Connell, 2010; Mudur, 2004; Lauridsen, 2009). Strictly speaking, the investment in pharmaceutical and medical technologies, medical education as well as healthcare facilitators; regardless of whether the investments are primarily expected solely for MT or helps encourage the productions of Thai medicines, the obsessive medical infrastructure allocation by the Thailand government in order to carry foreign expenditures to Thai hospitals is inevitably sucking an equally affordable medical-care away from Thai locals (Chongsuvivatwong et al., 2011; Cohen, 2008; Cohen et al., 1972). From general economic growth figures, with the biggest growth weight much heavily in Bangkok, the Northeast region of Thailand is receiving the growth gap consequences. With Bangkok's gross regional product of over 8.3 times higher than the Northeast in 2004 alone, the unequal social condition is inevitable. Consequently, despite perceived good growth of Thai's MT, the respondents' agreement on local's equal healthcare's service provider provision, and equal community's social service support provision are reflecting dissatisfaction.

From environmental assessment, the perceived growth of Thailand's tourism and the niche MT has validated strong agreements toward unequal policy impacts of local's environmental degradation (Alberti et al., 2014; Dang et al., 2020; Syah et al., 2021). The impact examination has never been so novel, and this research, has, in its capacity, underscoring the policy evidence of MT's focus on the environment. "This (tourism impact on the environment) is an important issue especially for developing countries where economic conditions are relatively dependent on natural resources and the environment - since, in reality, where tourism revenues are concerned, economic and environmental factors are opposite sides of a coin" (Wattanakuljarus, 2006: 5). As Wattanakuljarus (2006) extended, Thailand's service industry like MT relies heavily on land, forest, and piped water. Unfortunately to date, the politics on the management and national, or regional supply of water is still sparking sound conflicts of unfair land use and deterioration of green areas like forest and community landscapes (Wattanakuljarus, 2006) - the case is presumed to intolerantly impacting locals without political privileges and minimal access to environmental policy discourses (Syah et al., 2021). More severely on the water issue, "conflicts in water allocation are so serious that Thailand could face a water crisis in the near future unless water management and allocation are better managed" (Wattanakuljarus, 2006: 2). Tourism including MT are estimated to consume 300 liters/individual/day with up to 1,000 liters/guest/day for most upscale hotels (Wattanakuljarus, 2006). Eventually, despite a challenging search of literature reviews on Thailand's MT impact toward air, noise, as well as medical solid-toxic waste, the statistical significance from the overall framework of environmental impacts on the Thai's the local community has generalized an understanding that the environmental externalities of MT in Thailand are yet to be prioritized.

Table 8. Hypothesis Summary (Source: Authors)

\begin{tabular}{|c|c|c|}
\hline $\begin{array}{c}\mathrm{H} \\
1\end{array}$ & $\begin{array}{l}\text { The perceived growth of medical tourism in } \\
\text { Thailand has not been fully contributing to the } \\
\text { healthcare equality of the Thai local community }\end{array}$ & $\begin{array}{c}\text { Accep } \\
\text {-ted }\end{array}$ \\
\hline $\begin{array}{l}H \\
?\end{array}$ & $\begin{array}{l}\text { The perceived growth of medical tourism in } \\
\text { Thailand has not been fully contributing to the } \\
\text { economic equality of the Thai local community }\end{array}$ & $\begin{array}{c}\text { Accep } \\
\text {-ted }\end{array}$ \\
\hline $\begin{array}{l}\mathrm{H} \\
3\end{array}$ & $\begin{array}{l}\text { The perceived growth of medical tourism in } \\
\text { Thailand has not been fully contributing to the } \\
\text { social equality of the Thai local community }\end{array}$ & $\begin{array}{c}\text { Accep } \\
\text {-ted }\end{array}$ \\
\hline & $\begin{array}{l}\text { The perceived growth of medical tourism in } \\
\text { Thailand has not been fully contributing to the } \\
\text { environmental equality in the Thai local community }\end{array}$ & $\begin{array}{c}\text { Accep } \\
\text {-ted }\end{array}$ \\
\hline
\end{tabular}

\section{CONCLUSION}

The equality issue on local growth over the extensive spur of MT in Thailand has always been a major concern (Cohen, 2008). Yet, the studies of Thailand's MT's impact toward local wellbeing are still lacking. Hence, with a more systematic
Table 9. Resolution Coined at the $3^{\text {rd }}$ National Health Assembly (Source: NHC, 2017a; Modified from Kaewkamol and Lim, 2021)

Resolution 1 Overcoming crisis of injustice for the wellbeing of Thai society together

Resolution 2 Control of food marketing strategy for infants and young children

$\begin{array}{lll}\text { Resolution } 3 & \text { Fairness in access to health services by the disabled }\end{array}$ Resolution 4 Solving the problem of unplanned pregnancy in Thai teenagers

Resolution 5 Measures to make Thai society free from asbestos

\begin{tabular}{l|l} 
Resolution 6 & Measures on health risk factors particular on tobacco control
\end{tabular} \begin{tabular}{l|l} 
Resolution 7 & Policies to support self-management areas for social wellbeing \\
\hline
\end{tabular}

Resolution 8 Medical hub

\begin{tabular}{|l|l|} 
Resolution 9 & Protection of well-being and society from the impacts of free trade \\
\hline
\end{tabular} 
and comprehensive approach over economic, social, healthcare and environmental aspects, this research has proved the thesis statement and successfully furthered the examination of these perceived unequal impacts on Thai's local community. When the perceived growth of MT's in Thailand is understood to reflect positively on the overall's success of government economic initiatives, the impacts towards equal industry's benefits provision on economic, social, healthcare, and environment are still deemed contradicting - resulting in an understanding of negative externalities of MT development towards local wellbeing. All four hypotheses were approved. And that being said, even after a long hiatus from previous study on MT versus socio-economic equality (Cohen, 2008; Connell, 2010; Noree et al., 2016; Pocock and Phua, 2011), this new study interprets a conservative, rather static of the implementations of Thai's MT sound policy and integrated business strategy that are geared solely towards the support of specific, direct industry's beneficiaries. Where the wellbeing supports of stakeholders like Thai's local community are not yet to be fully identified over the MT's policy agenda. In other words, the issues of developmental policy isolation between MT's investments versus community benefits are still up in the air. In addition to the facts stated in the discussion section of this study, to put the approval of hypothesis into a perspective of Thailand's MT's governance, the phenomenon of perceived inequality can be straightforwardly associated by the argument of Thailand's ineffective, and less inclusive policy transfer (Syah et al., 2021). This particular policy approach has maintained the status quo of a bottleneck and bureaucratic overarching socioeconomic discourses within the non-elite communities in the Kingdom of Thailand. In contrast, however, MT's strategic plan per se, being proposed by Thailand's National Health Commission in 2017 (Table 9), exhibits an impressive, such a firm integration between the MT's vast investment and flourishing, well-deployed, and blanketed community's socioeconomic, and security empowerement. In fact, the commission being formed during Thailand's National Health Act in 2007 was lawfully set under the article of 13.1 and 13.2 whereby the prime minister and minister of public health voted as chair and vice-chair respectively - with inclusive member of board advisiors" (Kaewkamol and Lim, 2021, p. 10; NHC, 2017b), has set Thailand's MT apart, as one of the most prominent governances (Figure 1).

Of course, the narrative of this research finding can be resonated with the assumption of Thai's community overall dissatisfactions on their government political slants (ongoing people demands on a more transparent government, supremacy of democracy, monarchy constitutional laws review) in fact, there is a huge room for that argument. However, in this very case, what the study can see is merely tied by the exisiting literature which uncovered the issues, in a direct manner, between MT's investment and Thai's citizen wellbeing. In another occasion, nevertheless, the relationship study of MT's investment versus local wellbeing, mediated by a mere political point of view, can be conceptualized. Hence to bring back the focus, the inevitable power gap between the elites and

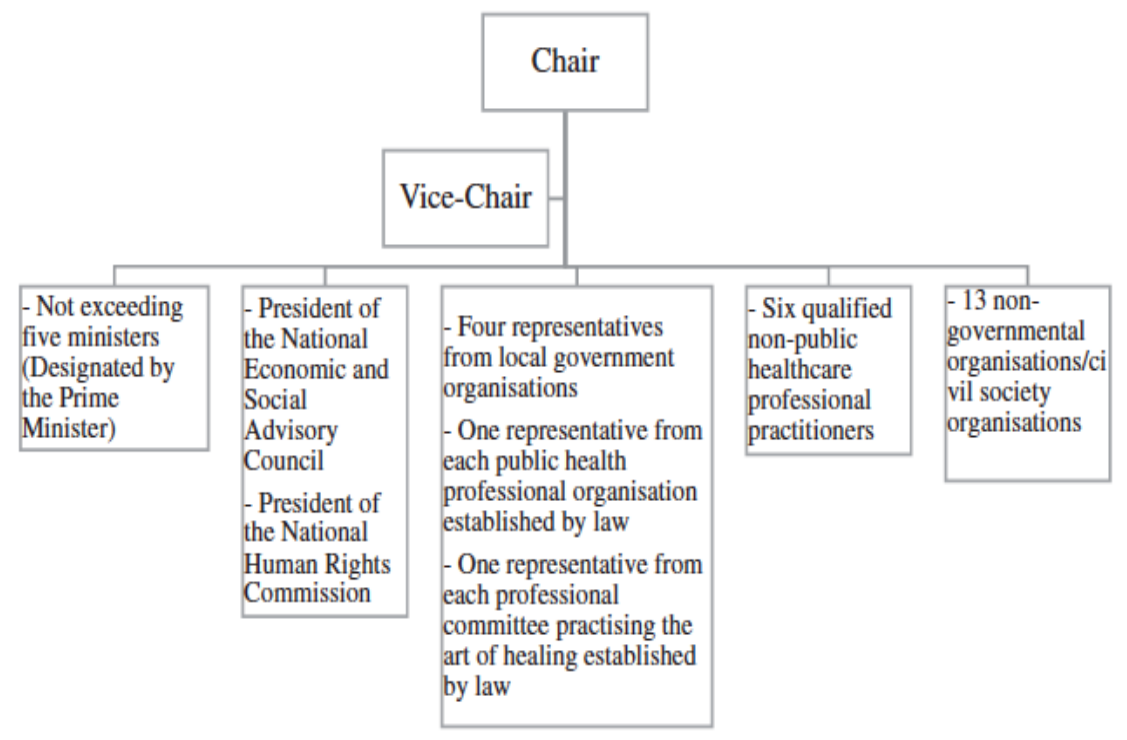

Figure 1. Organization Chart of National Health Comission

(Source: NHC, 2017b; Kaewkamol and Lim, 2021)

commoners (in this research:

Thai's medical doctors, resident doctors, medical students (senior year), and tourism scholars), has resulted in a big governance question as to how the unsolved alienation of Thailand's exclusive policy transfer over an efficacious governance of transparency and participation for Thai's local community can be all altered. Overall with the capacity of this study, this research is opening a clearer, more guided map for the furtherment of MT research over democratized social policy, political economy, environmental impacts, social and economic network management, and bottom-up business policy communications frameworks, to say the least.

\section{REFERENCES}

Alberti, F.G., Giusti, J.D., Papa, F., \& Pizzurno, E. (2014). Competitiveness policies for medical tourism clusters: Government initiatives in Thailand. International Journal of Economic Policy in Emerging Economies, 7(3), 281-309. https://doi.org/10.1504/IJEPEE.2014.065252

Aldiabat, K.M., \& Le Navenec, C. (2018). Data Saturation: The Mysterious Step in Grounded Theory Methodology Carole-Lynne Le Navenec. The Qualitative Report, 23(1), 245-261, on 20 June 2021. https://nsuworks.nova.edu/tqr/vol23/iss 1/18/

Almeida García, F., Balbuena Vázquez, A., \& Cortés Macías, R. (2015). Resident's attitudes towards the impacts of tourism. Tourism Management Perspectives, 13, 33-40. https://doi.org/10.1016/j.tmp.2014.11.002

Andereck, K.L., \& Nyaupane, G.P. (2011). Exploring the Nature of Tourism and Quality of Life Perceptions among Residents. Journal of Travel Research, 50(3), 248-260. https://doi.org/10.1177/0047287510362918

Bangkok Chain Hospital. (2017). Annual Report 2017. Bangkok: Bangkok Chain Hospital Public Company Limited. Bangkok. on 3 June 2021. https://www.bangkokchainhospital.com/uploads/file/annual_report2017_en.pdf

Bookman, M.Z., \& Bookman, K.R. (2007). Medical tourism in developing countries. New York: Palgrave Macmillan. https://doi.org/ $10.1057 / 9780230605657$ 
Bramwell, B., \& Lane, B. (1993). Sustainable tourism: An evolving global approach. Journal of Sustainable Tourism, 1(1), 1-5. https://doi.org/10.1080/09669589309450696

Cham, T.H., Lim, Y.M., Sia, B.C., Cheah, J.H., \& Ting, H. (2020). Medical Tourism Destination Image and its Relationship with the Intention to Revisit: A Study of Chinese Medical Tourists in Malaysia. Journal of China Tourism Research, 17(2), 163-191. https://doi.org/10.1080/19388160.2020.1734514

Chongsuvivatwong, V., Hong, P.K., Yap, M.T., Pocock, N.S., Hashim, J.H., Chhem, R., Agus, S.W., \& Lopez, A.D. (2011). Health and healthcare systems in southeast Asia: diversity and transitions. Lancet, 377(9763), 429-37. https://doi.org/10.1016/S0140- 6736(10)61507-3

Chuck, Y.G., Dexter, J.L., Choy, \& James, C.M. (1985). The Travel Industry. Journal of Travel Research, 23(3), 34-34. https://doi.org/https://doi.org/10.1177/004728758502300310

Clare, A.G., \& Var, T. (2002). Tourism Planning (4th ed.). Taylor \& Francis. https://doi.org/10.4324/9781003061656

Cohen, E. (2007). Tsunami and Flash-floods-Contrasting Modes of Tourism-related Disasters in Thailand. Tourism Recreation Research, 32(1), 21-39. https://doi.org/https://doi.org/10.1080/02508281.2007.11081521

Cohen, E. (2008). Medical Tourism in Thailand. AU-GSB e-Journal, 1(1), 24-37. http://www.assumptionjournal.au.edu/index.php/AUGSB/article/view/381/335 on 7 April 2021.

Cohen, E., Hilton, I., Bar-Yoseph, R., Katz, E., \& Shoke, M. (1972). Toward a Sociology of International Tourism Toward a Sociology of International Tourism. Social Research: An International Quarterly, 39(1), 164-182. https://www.jstor.org/stable/40970087

Connell, J. (2006a). Medical tourism: Sea, sun, sand and surgery. Tourism Management, 27(2006), 1093-1100. https://doi.org/10.1016/j.tourman.2005.11.005

Connell, J. (2006b). Medical Tourism: The Newest of Niches. Tourism Recreation Research, 31(1), 99-102. http://dx.doi.org/ $10.1080 / 02508281.2006 .11081252$

Connell, J. (2010). Migration and the globalisation of health care: The health worker exodus? Edward Elgar Publishing. https://doi.org/10.4337/9781849805186

Connell, J. (2011). A new inequality? Privatisation, urban bias, migration and medical tourism. Asia Pacific Viewpoint, 52(3), $260-271$. https://doi.org/10.1111/j.1467-8373.2011.01454.x

Connell, J. (2013). Contemporary medical tourism: Conceptualisation, culture and commodification. Tourism Management, 34(2013), 113. https://doi.org/10.1016/j.tourman.2012.05.009

Dang, H.S., Nguyen, T.M.T., Wang, C.N., Day, J.D, \& Dang, T.M.H. (2020). Grey system theory in the study of medical tourism industry and its economic impact. International Journal of Environmental Research and Public Health, 17(3), 1-23. https://doi.org/10.3390/ijerph17030961

Filkins, R., Allen, J.C., \& Cordes, S. (2000). Predicting community satisfaction among rural residents: An integrative model. Rural Sociology, 65(1), 72-86. https://doi.org/10.1111/j.1549-0831.2000.tb00343.x

Glinos, I.A., Baeten, R., Helble, M., \& Maarse, H. (2010). A typology of cross-border patient mobility. Health and Place, 16(6), 114555. https://doi.org/10.1016/j.healthplace.2010.08.001

Goudy, W.J. (1990). Community Attachment in a Rural Region. Rural Sociology, 55(2), 178-198. https://doi.org/10.1111/j.15490831.1990.tb00679.x

Grzeskowiak, S., Sirgy, M.J., \& Widgery, R. (2003). Resident's satisfaction with community services: Predictors and outcomes. Journal of Regional Analysis and Policy, 33(2), 1-36. https://doi.org/10.22004/ag.econ.132251

Hansruedi, M. (1994). The thorny path to sustainable tourism development. Journal of Sustainable Tourism, 2(3), 131-136. https://doi.org/https://doi.org/10.1080/09669589409510690

Haywood, K.M. (1988). Responsible and responsive tourism planning in the community. Tourism Management, 9(2), $105-118$. https://doi.org/10.1016/0261-5177(88)90020-9

Heung, V.C.S., Kucukusta, D., \& Song, H. (2010). A conceptual model of medical tourism: Implications for future research. Journal of Travel and Tourism Marketing, 27(3), 236-251. https://doi.org/10.1080/10548401003744677

Hopkins, L., Labonté, R., Runnels, V., \& Packer, C. (2010). Medical tourism today: What is the state of existing knowledge. Journal of Public Health Policy, 31(2), 185-98. https://doi.org/10.1057/jphp.2010.10

Izadi, M., Ayoobian, A., Nasiri, T., Joneidi, N., Fazel, M., \& Hosseinpourfard, M.J. (2012). Situation of health tourism in Iran; Opportunity or threat. Journal of Military Medicine, 14(2), 69-75. http://militarymedj.ir/article-1-1004-en.html

Johnson, J.D., Snepenger, D.J., \& Akis, S. (1994). Residents' perceptions of tourism development. Annals of Tourism Research, 21(3), 629-42. https://doi.org/10.1177/004728759403300235

Johnston, R., Crooks, V.A., Snyder, J., \& Kingsbury, P. (2010). What is known about the effects of medical tourism in destination and departure countries? A scoping review. International Journal for Equity in Health, 9(24), 1-13. https://doi.org/10.1186/1475-9276-9-24

Kaewkamol, P., \& Lim, G. (2021). Neo-Liberalism, the Rise of the Unelected and Policymaking in Thailand: The Case of the Medical Tourism Industry. Journal of Contemporary Asia, 51(3), 447-468. https://doi.org/https://doi.org/10.1080/00472336.2020.1740294

Kasarda, J.D., \& Janowitz, M. (1974). Community Attachment in Mass Society. American Sociological Review, 39(3), $328-339$. https://doi.org/10.2307/2094293

Khan, M.J., Chelliah, S., Haron, M.S., \& Ahmed, S. (2017). Role of travel motivations, perceived risks and travel constraints on destination image and visit intention in medical tourism: Theoretical model. Sultan Qaboos University Medical Journal, 17(1), e11e17. https://doi.org/10.18295/squmj.2016.17.01.003

Kim, H., Woo, E., \& Uysal, M. (2015). Tourism experience and quality of life among elderly tourists. Tourism Management, 46, 465476. https://doi.org/10.1016/j.tourman.2014.08.002

Kuvan, Y., \& Akan, P. (2005). Residents' attitudes toward general and forest-related impacts of tourism: The case of Belek, Antalya. Tourism Management, 26(5), 691-706. https://doi.org/10.1016/j.tourman.2004.02.019

Laugesen, M.J., \& Vargas-Bustamante, A. (2010). A patient mobility framework that travels: European and United States-Mexican comparisons. Health Policy, 97(2), 225-231. https://doi.org/10.1016/j.healthpol.2010.05.006

Lauridsen, L. (2009). The Policies and Politics of Industrial Upgrading in Thailand during the Thaksin Era (2001-2006). Asian Politics and Policy, 1(3), 409-434. 10.1111/j.1943-0787.2009.01133.x

Lawrence, R.A., Patrick, T.L., Richard, R.P., \& Scott, K. (1988). The Impact Of Tourism Development On Residents' Perceptions Of Community Life. Journal of Travel Research, 27(1), 16-21. https://doi.org/https://doi.org/10.1177\%2F004728758802700104

Liu, J.C., Sheldon, P.J., \& Var, T. (1987). Resident perception of the environmental impacts of tourism. Annals of Tourism Research, 14(1), 17-37. https://doi.org/10.1016/0160-7383(87)90045-4 
Liu, J.C., \& Var, T. (1986). Resident attitudes toward tourism impacts in Hawaii. Annals of Tourism Research, 12(3), $193-214$. https://doi.org/10.1016/0160-7383(86)90037-X

McCabe, S., \& Johnson, S. (2013). The happiness factor in tourism: Subjective well-being and social tourism. Annals of Tourism Research, 41(2013), 42-65. https://doi.org/10.1016/j.annals.2012.12.001

Mccool, S.F., \& Martin, S.R. (1994). Community Attachment and Attitudes Toward Tourism Development. Journal of Travel Research, 32(3), 29-34. https://doi.org/10.1177/004728759403200305

McGehee, N.G., \& Andereck, K.L. (2004). Factors predicting rural residents' support of tourism. Journal of Travel Research, 43(2004), 131-140. https://doi.org/10.1177/0047287504268234

Mudur, G. (2004). Hospitals in India woo foreign patients. BMJ (Clinical Research Ed.), $328(7452), \quad 1338$. https://doi.org/10.1136/bmj.328.7452.1338

Noree, T., Hanefeld, J., \& Smith, R. (2016). Le tourisme médical en Thaillande: Étude transversale. Bulletin of the World Health Organization, 94(1), 30-36. https://doi.org/10.2471/BLT.14.152165

Nunkoo, R., \& Ramkissoon, H. (2012). Power, trust, social exchange and community support. Annals of Tourism Research, 39(2), 9971023. https://doi.org/10.1016/j.annals.2011.11.017

Pearce, P.L. (2009). The Relationship Between Positive Psychology and Tourist Behavior Studies. Tourism Analysis, 14(1), 37-48. https://doi.org/https://doi.org/10.3727/108354209788970153

Perdue, R.R., Long, P.T., \& Allen, L. (1990). Resident support for tourism development. Annals of Tourism Research, 17(4), 586-599. https://doi.org/10.1016/0160-7383(90)90029-Q

Pocock, N.S., \& Phua, K.H. (2011). Medical tourism and policy implications for health systems: A conceptual framework from a comparative study of Thailand, Singapore and Malaysia. Globalization and Health, 7(2), 1-12. https://doi.org/10.1186/1744-8603-7-12

Raggio, B.S., Brody-Camp, S.A., Jawad, B.A., Winters, R.D., \& Aslam, R. (2020). Complications Associated with Medical Tourism for Facial Rejuvenation: A Systematic Review. Aesthetic Plastic Surgery, 44(3), 1058-1065. https://doi.org/10.1007/s00266-020-01638-w

Sharpley, R. (2000). Tourism and Sustainable Development: Exploring the Theoretical Divide. Journal of Sustainable Tourism, 8(1), 119. https://doi.org/https://doi.org/10.1080/09669580008667346

Sirgy, M.J., \& Cornwell, T. (2001). Further validation of the Sirgy et al.'s measure of community quality of life. Social Indicators Research, 56(2001), 125-143. https://doi.org/10.1023/A:1012254826324

Sirgy, M.J., Rahtz, D.R., Cicic, M., \& Underwood, R. (2000). A method for assessing residents' satisfaction with community-based services: A quality-of-life perspective. Social Indicators Research, 49(2000), 279-316. https://doi.org/10.1023/A:1006990718673

Suess, C., Baloglu, S., \& Busser, J.A. (2018). Perceived impacts of medical tourism development on community wellbeing. Tourism Management, 69, 232-245. https://doi.org/10.1016/j.tourman.2018.06.006

Syah, A.M., Li, L.Y., Syukur, M., Wu, T.J., \& Boon, V. (2021). The Implication of Transnational Communication Framework on Domestic Plastic Policy Understanding. A Study of Tourism's SMEs in Thailand. Journal of Environmental Management and Tourism, 12(5), 1155-1170. https://doi.org/https://doi.org/10.14505//jemt.v12.5(53).01

Thompson, C. (2008). Medical tourism, stem cells, genomics: EASTS, transnational STS, and the contemporary life sciences. East Asian Science, Technology and Society, 2(3), 433-438. https://doi.org/10.1007/s12280-008-9056-3

Thompson, C. (2011). Medical migrations afterword: Science as a vacation? Body and Society, 17(2\&3), $205-213$. https://doi.org/10.1177/1357034X11405549

Udomvej, T. (2018). Company Research: Chularat Hospital. Bangkok: Krungsri Securities. on 2 June 2021. https://www.krungsrisecurities. com/images.aspx?filename=http://www.krungsrisecurities.com/uploads/2018/07/research_en_US_6032_1_CHG_180731_U.pdf

Uysal, M., Sirgy, M.J., Woo, E., \& Kim, H.L. (2016). Quality of life (QOL) and well-being research in tourism. Tourism Management, 53, 244-261. https://doi.org/10.1016/j.tourman.2015.07.013

Wattanakuljarus, A. (2006). The Nationwide Economic and Environmental Impacts of Tourism: A Computable General Equilibrium Approach for Thailand, EEPSEA Special and Technical Paper tp200607t1, Economy and Environment Program for Southeast Asia (EEPSEA), on 10 June 2021. https://ideas.repec.org/p/eep/tpaper/tp200607t1.html

Weaver, D.B. (2005). Sustainable Tourism (1st Edition). Routledge. https://doi.org/https://doi.org/10.4324/9780080474526

Weaver, D.B., \& Lawton, L.J. (2001). Resident perceptions in the urban-rural fringe. Annals of Tourism Research, 28(2), 439-458. https://doi.org/10.1016/S0160-7383(00)00052-9

Wongkit, M., \& McKercher, B. (2016). Desired Attributes of Medical Treatment and Medical Service Providers: A Case Study of Medical Tourism in Thailand. Journal of Travel \& Tourism Marketing, 33(1), 14-27. https://www.tandfonline.com/ doi/full/10.1080/10548408.2015.1024911

Zarei, A., Feiz, D., Maleki Minbashrazgah, M., \& Maleki, F. (2018). Factors influencing selection of medical tourism destinations: A special niche market. International Journal of Healthcare Management, 13(S1), 192-198. https://doi.org/10.1080/20479700.2018.1492764

Zarei, A., \& Maleki, F. (2019). Asian medical marketing, a review of factors affecting Asian medical tourism development. Journal of Quality Assurance in Hospitality and Tourism, 20(1), 1-15. https://doi.org/10.1080/1528008X.2018.1438959

Zikmund, W.G., Babin, B.J., Carr, J.C., \& Griffin, M. (2010). Business Research Methods ( $8^{\text {th }}$ ed.). Canada: Cengage Learning.

*** Dusit Medical. 2017. Annual Report 2017. Bangkok: Bangkok Dusit Medical Services Public Company Limited. on 2 June 2021. https://bdms.listedcompany.com/misc/ar/20180309-bdms-ar2017-en-05.pdf

***KPMG. (2018). Medical Tourism: Industry Focus on 1 June 2021. https://assets.kpmg/content/dam/kpmg/th/pdf/2018/03/th-medicaltourism-industry-focus-secured.pdf

*** NHC. (2017a). 3rd National Health Assembly. National Health Commission, on 13 June 2021. https://en.nationalhealth.or.th/3rdnational-health-assembly/

*** NHC. (2017b). Our Structure. National Health Commission. on 13 June 2021. https://en. nationalhealth.or.th/our-structure/

*** TAT. (2020). Kiawkub roaw: Wisaitut and Puntakit [About Us: Vision and Mission]. Tourism Authority of Thailand. on 5 June 2021. https://www.tat.or.th/th/about-tat/vision

*** TIR. (2020). Thailand Medical Destination: Finding Wealth in Wellness. Thailand Investment Review, on 01 June 2021. https://www.boi.go.th/upload/content/TIRMay2020.pdf 